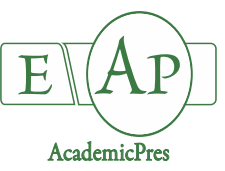

MA W-Y et al. (2021)

Notulae Botanicae Horti Agrobotanici Cluj-Napoca

Volume 49, Issue 2, Article number 12363

DOI: $10.15835 /$ nbha 49212363

Review Article

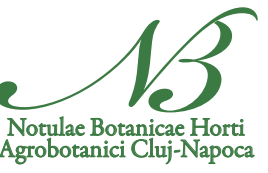

\title{
Exploring mycorrhizal fungi in walnut with a focus on physiological roles
}

\author{
Wen-Ya MA ${ }^{1}$, Qiang-Sheng WU ${ }^{1,4 *}$, Yong-Jie XU' ${ }^{2,3 *}$, Kamil KUČA ${ }^{4}$ \\ ${ }^{1}$ Yangtze University, College of Horticulture and Gardening, Jingzhou, Hubei 434025, China; \\ 1436593595@qq.com; wuqiangsh@163.com(*corresponding author) \\ ${ }^{2}$ Hubei Key Laboratory of Economic Forest Germplasm Improvement and Resources Comprehensive Utilization, Hubei \\ Collaborative Innovation Center for the Characteristic Resources Exploitation of Dabie Mountains, \\ Huanggang Normal University, Huanggang 438000, China; \\ ${ }^{3}$ Hubei Academy of Forestry, Wuhan, Hubei 430075, China; 498674563@qq.com (*corresponding author) \\ ${ }^{4}$ University of Hradec Kralove, Faculty of Science, Department of Chemistry, Hradec Kralove 50003, \\ Czech Republic; kamil.kuca@uhk.cz
}

\begin{abstract}
Walnuts are an economically important forest tree used for timber and nut production, and the nut of fruits is rich in various nutrients, becoming one of the four important nuts in the world. Walnuts have deep roots, which can be colonized by either ectomycorrhizal fungi or arbuscular mycorrhizal fungi in the soil. These mycorrhizal fungi form beneficial symbioses in roots of walnut. A large number of ectomycorrhizal fungi have been identified, whilst Boletus edulis, Calvatia uiacina, and Cantharelles cibariusisolated from walnut orchards stimulated plant growth and gave the capacity of stress tolerance in walnut. Moreover, Carya illinoensis is a very good host plant for commercial production of truffles, especially Tuber indicum. In addition, ectomycorrhizal fungi accelerate plant growth and enhance potential stress tolerance of walnuts. Inoculation with arbuscular mycorrhizal fungi also showed the improvement of plant growth and nutrient acquisition of walnut, the enhancement of drought tolerance in walnut, nutrient redistribution under walnut interplanting patterns, and the delivery of juglone by mycorrhizal hyphae. A culturable in vitro arbuscular mycorrhizal like fungus Piriformospora indica also enhanced salt tolerance of walnut plants. In this mini-review, the physiological roles of mycorrhizal fungi, including arbuscular mycorrhizal fungi, ectomycorrhizal fungi and arbuscular mycorrhizal like fungus $(P$. indica) on walnut plants are summarized, and future outlooks in the field are proposed.
\end{abstract}

Keywords: endophytic fungi; mycorrhiza; nut trees; symbiosis; truffle

\section{Introduction}

Walnut (Juglans regia L.) is a deciduous fruit tree, originating in northwest China. Walnut is one of the world's famous "four nut fruits" along with lentil, cashew and hazelnut (Shi et al., 2018). Walnuts bloom in spring and bear fruit in autumn, and their kernels are rich in nutritional value, including unsaturated fatty acids, proteins, vitamins B1 and E, iron, and selenium (Bender and Bender, 2005). Walnuts have a long history of

Received: 30 Apr 2021. Received in revised form: 14 Jun 2021. Accepted: 16 Jun 2021. Published online: 18 Jun 2021.

From Volume 49, Issue 1, 2021, Notulae Botanicae Horti Agrobotanici Cluj-Napoca journal uses article numbers in place of the traditional method of continuous pagination through the volume. The journal will continue to appear quarterly, as before, with four annual numbers. 
cultivation in both the north and south of China, and fossilized walnut pollen has been found by Chinese archaeologists at the Hanpo clan site in Shaanxi Province, which is more than 6000 years old.

Mycorrhiza is a prevalent symbiosis in nature, which is a combination of mycorrhizal fungi in the soil and plant roots (Brundrett et al., 2009; Pohjanen et al., 2014). Mycorrhiza can improve the absorption of mineral elements in the soil, and also enhance the ability of host plants to resist drought, flooding, salinity, pests and diseases, change root system architecture, and increase photosynthesis, soil structure, and fruit quality of plants, thus, playing an important role in sustainable agriculture and environment (Wu et al., 2017; Zhang et al., 2019; Xie et al., 2021; Zou et al., 2021a, 2021b). According to morphology and anatomy, mycorrhizae can be divided into three major groups: ectomycorrhizae, endomycorrhizae, and ectendomycorrhizae (Jin et al., 2004; Lin et al., 2013). Of them, arbuscular mycorrhiza fungi (AMF), the most widespread fungi in the soil, can form arbuscular mycorrhiza (one of endomycorrhizae) with most plants (Wu et al., 2013). The fruit tree species with arbuscular mycorrhizae include citrus, apple, plum, pear, date, peach, grape, apricot, avocado, pear, pistachio, pomegranate, fig, pistachio, persimmon, loquat, hawthorn, kiwi, walnut, cherry, strawberry, banana, lychee, pineapple, longan, and mango. There are about 32 species of AMF studied and utilized in China. Liu et al. (2002) indicated that walnut is also capable of producing ectomycorrhizae, while He et al. (2013a, 2013b) proposed that walnut is a woody plant with a strong mycorrhizal dependence. As a result, walnut belongs to the plant having ectomycorrhizae and endomycorrhizae (Figure 1a, 1b), which deserves to be noticed. These mycorrhizal fungi have been found in the rhizosphere of walnut cultivated in the field, and many potted experiments also revealed various positive impacts of the inoculation with mycorrhizal fungi on walnut, as shown in Figure 2.

AMF can significantly and effectively improve plant growth of the host. Zou et al. (2021b) concluded through potted experiments that inoculation of AMF under soil water deficit conditions could dramatically increase growth responses of citrus plants, along with the improvement of root hairs and hormone balance (Zhang et al., 2019). Song et al. (2005) proved that the plant height, ground diameter and total biomass of the poplar inoculated with AMF were considerably higher than those of the uninoculated poplar. Chen et al. (2018) proved the stimulated effect of AMF on iris, and the positive effect mainly reflected on the plant growth, chlorophyll content, nitrate reductase activity, peroxidase activity, total root length, root specific surface area, root volume, and root average diameter that were significantly increased. Such experimental results fully reveal the positive effect of mycorrhizal fungi on the host.

The purpose of this review is to simply summarize the physiological roles of walnut plants by AMF, ectomycorrhizal (ECM) fungi, and arbuscular mycorrhizal like fungus Piriformospora indica (Figure 3), so as to promote the application of mycorrhizal fungi in the walnut industry.

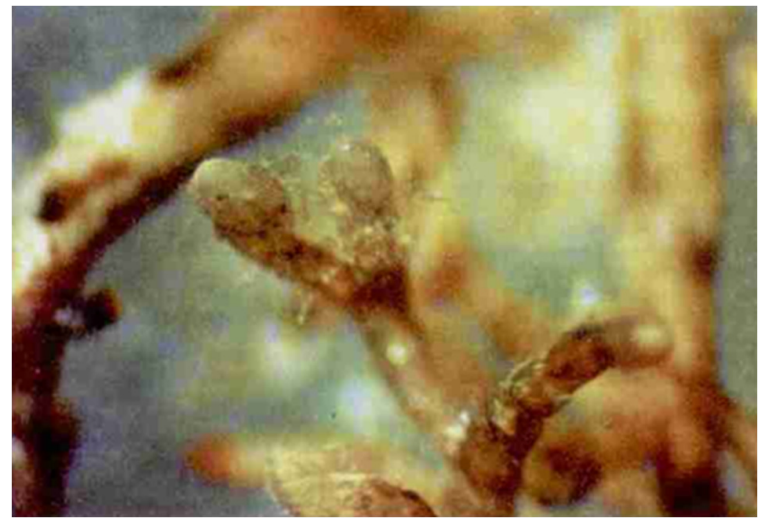

(a)

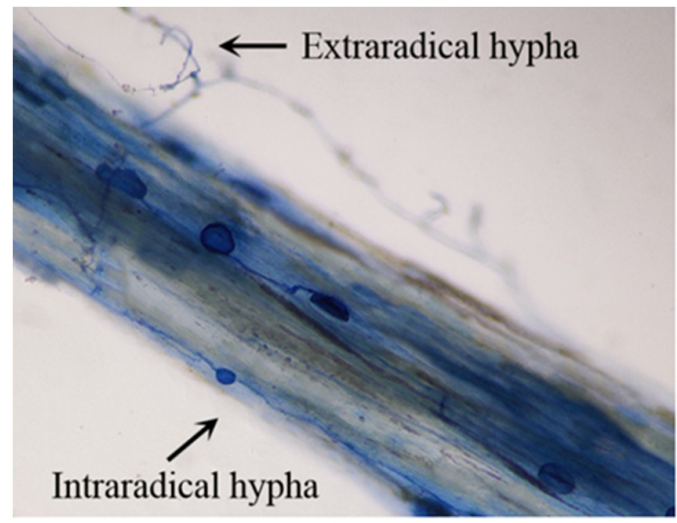

(b)

Figure 1. Mycorrhizal colonization of walnut plants. (a) Carya illinoensis after inoculated with ectomycorrhizal Tuber spp. (Yang et al. 2015); (b) Juglans regia L. Liaohe 1 after inoculated with an arbuscular mycorrhizal fungus Diversispora spurca (unpublished data) 


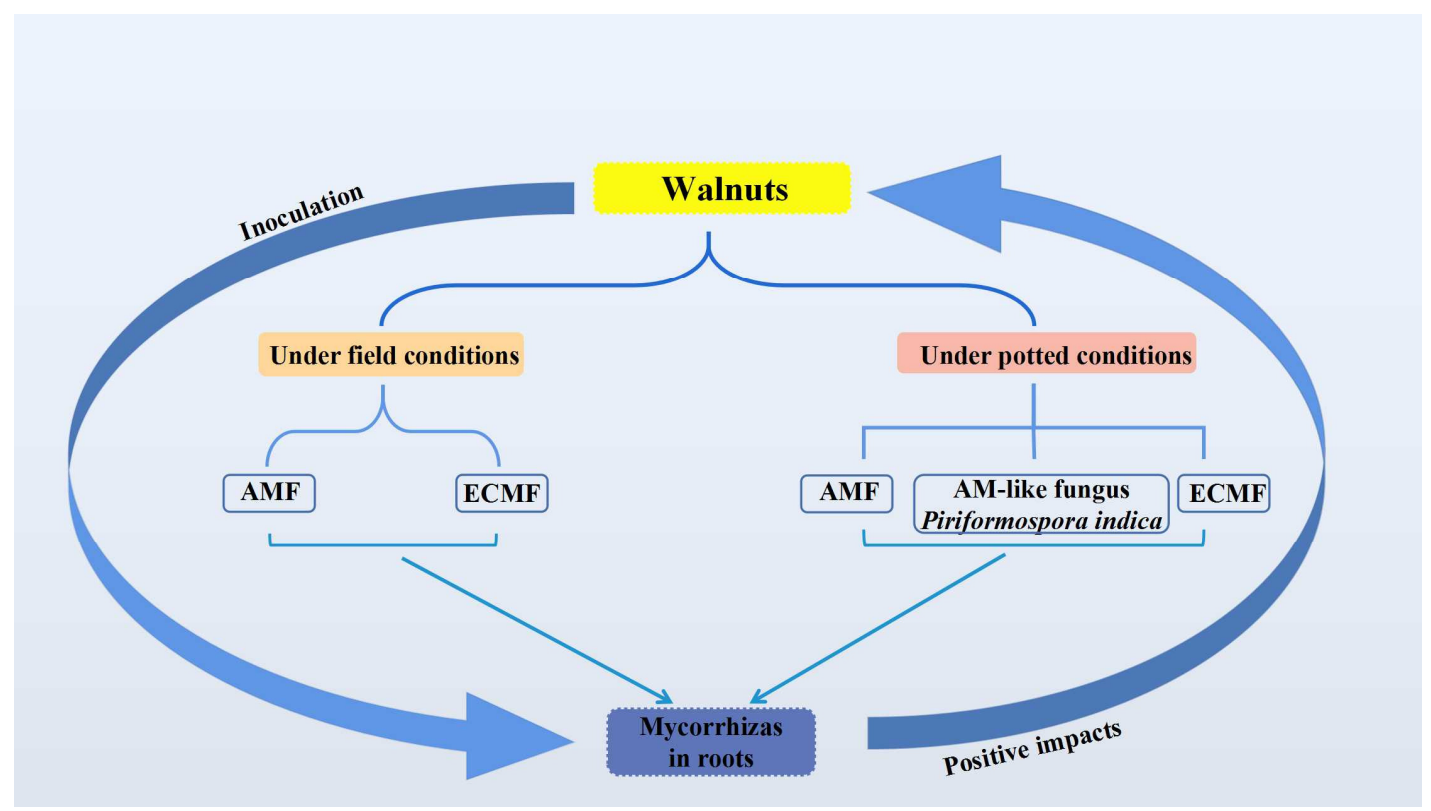

Figure 2. Overall overview on walnut and mycorrhizal fungi

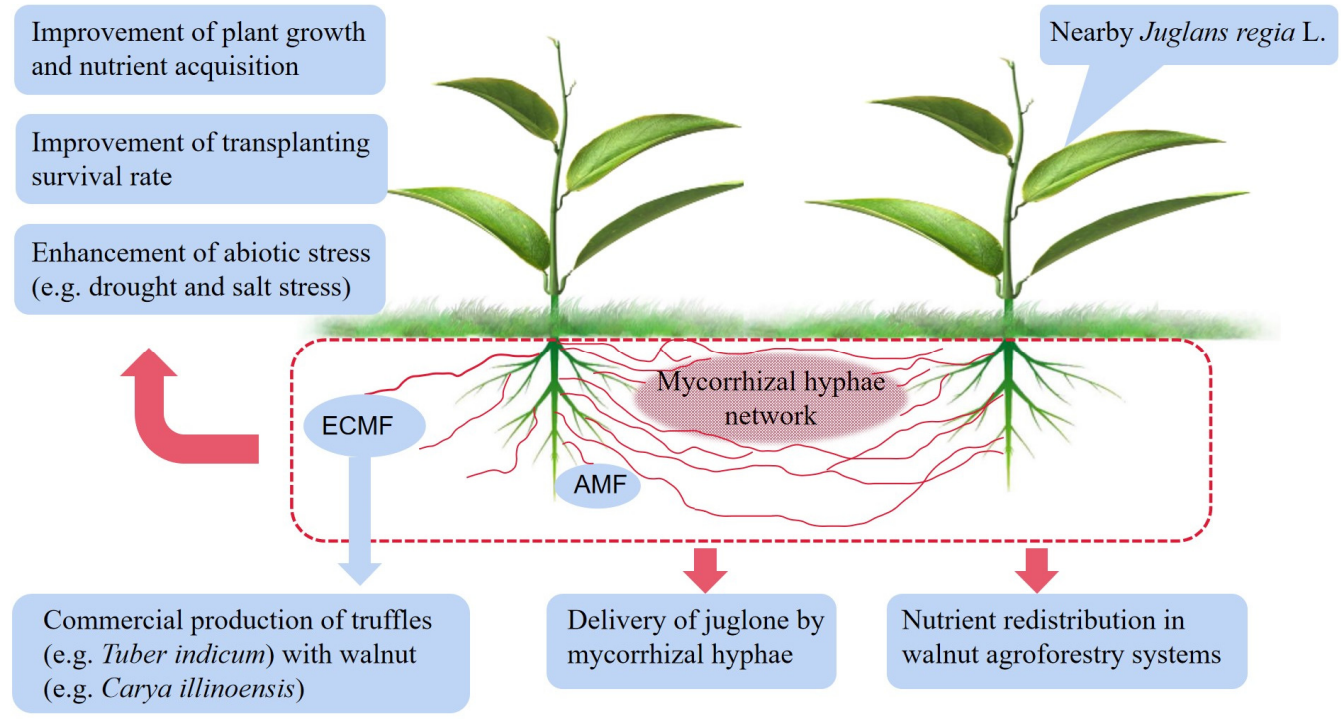

Figure 3. A diagram regarding mycorrhizal fungal roles in physiological activities of walnut plants. The rhizosphere of walnut inhabits both ectomycorrhizal fungi (ECMF) and arbuscular mycorrhizal fungi (AMF), which have positive effects on plant growth, nutrient uptake and redistribution, abiotic stress tolerance, and delivery of juglone by mycorrhizal hyphae network between plants. In addition, walnut e.g. Carya illinoensis becomes an important host used for commercial production of truffles (e.g. Tuber indicum) 


\section{Physiological roles of arbuscular mycorrhizal fungi in walnut}

\section{Improvement of growth and nutrient acquisition}

A huge spectrum of previous investigations have proved that AMF are of great help to plants under stress, and it has also been documented that AMF can co-exist with walnut root systems, which is helpful to walnut seedling growth. Wang (2015) inoculated potted walnut seedlings with three different AMF species, namely, Glomus versiforme, G. intraradices, and Diversispora suprcum, and found that the root colonization rate of $G$. versiforme to walnut seedlings was the highest, and thus this mycorrhizal fungus might be one of the dominant strains of walnut seedlings. And, the AMF-inoculated walnut plants showed greater plant height, stem diameter, biomass production, and leaf number and lower root:shoot ratio than non-AMF-inoculated plants, dependent on AMF species. However, although AMF-colonized walnut plants recorded higher tissue water content and contents of chlorophyll, starch, soluble sugar and soluble protein in leaves than non-AMF controls, there was no significant difference among the three mycorrhizal fungi-inoculated seedlings. In addition, if AMF (e.g. G. fasciculatus) inoculation combined with foliar-fertilized N, P, and N+P fertilizer in black walnut (Juglans nigra L.), such treatment would be an important factor in increasing growth and survival of outplanted walnut seedlings (Ponder, 1984). So AMF can shorten the time to the seedling stage of walnuts. Mortier et al. (2020) summarized that the AMF-improved nutrient absorption of walnut is associated with lateral roots, but not with pioneer roots.

Cheng et al. (2020) analyzed the effects of five AMF species (Acaulospora scrobiculata, D. spurca, G. etunicatum, $G$. mosseae, and $G$. versiforme) on biomass and leaf physiological activity of walnut seedlings. These AMF accelerated the production of stem and root biomass of walnut, and also increased the content of $\mathrm{P}, \mathrm{K}, \mathrm{Mg}, \mathrm{B}, \mathrm{Fe}, \mathrm{Zn}$, and $\mathrm{Cu}$ in leaves, whilst $G$. versiforme represented the potential effect. The stimulated nutrient acquisition also was found in drought-stressed walnut plants after AMF inoculation. $G$. mosseae, $G$. etunicatum, and the mix of both collectively increased leaf $\mathrm{N}, \mathrm{P}$, and $\mathrm{Zn}$ contents of walnut under normal water and drought stress conditions (Behrooz et al., 2019). In Juglans regia L. Liaohe 1, Huang et al. (2020) used five AMF species (A. scrobiculata, D. spurca, G. etunicatum, G. mosseae, and $G$. versiforme) and found that the AMF inoculations could improve plant growth performance, dependent on AMF species. Similarly, nutrient improvement after AMF inoculation was dependent on AMF species and nurient elements. Dolcet-Sanjuan et al. (1996) also showed that the survival rate of micropropagated walnut seedlings inoculated with $G$. mosseae and $G$. intraradices was significantly improved after being transferred to the nursery. As a result, AMF could confer protection against stress situation due to the tranplant process. In Eastern black walnut seedlings, inoculation with $G$. microcarpus, $G$. mosseae, or $G$. microcarpus $+G$. fasciculatus showed superior growth and development of seedlings (Melichar et al., 1986). Hence, early application of AMF may be beneficial in stimulating early growth and survival of outplanted walnut stock, which is due to the improvement of lateral roots and P contents, dependent on AMF and host species (Mortier et al., 2020).

\section{Variable root mycorrhizal colonization and nutrient redistribution under interplanting patterns}

Li et al. (2021) studied the correlation between soil factors and arbuscular mycorrhizae of walnut under different interplanting patterns. They found that walnut formed a good mycorrhizal symbiosis with soil AMF in Yunnan Plateau mountainous area. In addition, the highest mycorrhizal colonization rate of walnut roots was found in the interplanting pattern of walnut and tea tree, followed by the interplanting of walnut and maize, the interplanting of walnut and wheat, and the interplanting of walnut and pea in the decreasing order. This implies that interplanting plant species strongly influence the mycorrhizal status of walnuts. Therefore, the selection of interplanting plants in walnut orchards for mycorrhizal growth has to be studied in the future.

Tuinen et al. (2020) further found that in a walnut-maize agroforestry system, a common mycorrhizal network linked roots of both plants. Moreover, the part $\mathrm{C}$ from walnut trees could be transferred to maize plants, suggesting nutritional redistribution in such agroforestry ecosystems. The nutrient transferring would facilitate the redistribution of resources, which in turn promotes the recycling and reuse of nutrients. 
MA W-Y et al. (2021). Not Bot Horti Agrobo 49(2):12363

Table 1. Physiological roles of mycorrhizal fungi in walnut plants

\begin{tabular}{|c|c|c|c|c|}
\hline Walnuts & $\begin{array}{l}\text { Mycorrhizal } \\
\text { types }\end{array}$ & $\begin{array}{l}\text { Mycorrhizal } \\
\text { fungi }\end{array}$ & $\begin{array}{c}\text { Mycorrhizal effects on } \\
\text { walnut }\end{array}$ & References \\
\hline Juglans regia $\mathrm{L}$. & \multirow{6}{*}{$\begin{array}{l}\text { Arbuscular } \\
\text { mycorrhiza }\end{array}$} & $\begin{array}{c}\text { Glomus versiforme, } \\
\text { G. intraradices, and } \\
\text { Diversispora suprcum }\end{array}$ & $\begin{array}{c}\text { growth target } \uparrow ; \\
\text { chlorophyll } \uparrow ; \text { soluble } \\
\text { sugar content } \uparrow ; \text { starch } \\
\text { content } \uparrow ; \text { protein } \\
\text { content } \uparrow ; \\
\text { malondialdehyde } \downarrow\end{array}$ & (Wang et al., 2015) \\
\hline $\begin{array}{l}\text { J. regia L. var. } \\
\text { 'Liaohe 1' }\end{array}$ & & $\begin{array}{c}\text { Acaulospora scrobiculata, } \\
\text { D. spurca, G. etunicatum, } \\
\text { G. mosseae, and } \\
\text { G. versiforme }\end{array}$ & $\begin{array}{c}\text { shoot and root biomass } \uparrow \text {; } \\
\text { chlorophyll a } \uparrow \text {; } \\
\text { chlorophyll b } \text {; total } \\
\text { chlorophyll } \uparrow \text {; glucose } \downarrow \text {; } \\
\text { fructose } \downarrow \text {; sucrose } \uparrow\end{array}$ & (Cheng et al., 2020) \\
\hline J. regia L. & & $\begin{array}{l}\text { G. mosseae and } \\
\text { G. intraradices }\end{array}$ & survival $\uparrow$ & $\begin{array}{c}\text { (Dolcet-Sanjuan et } \\
\text { al., 1996) }\end{array}$ \\
\hline $\begin{array}{l}\text { J. regia L. var. } \\
\text { 'Liaohe 1' }\end{array}$ & & $\begin{array}{l}\text { A. scrobiculata, } \\
\text { D. spurca, G. etunicatum, } \\
\text { G. mosseae, and } \\
\text { G. versiforme }\end{array}$ & $\begin{array}{c}\text { root length } \uparrow ; \text { projected } \\
\text { area } \uparrow \text {; surface area } \uparrow ; \\
\text { volume } \uparrow \text {; plant growth } \uparrow ; \\
\text { nutrient improvement } \\
\text { and gas exchange } \\
\text { depended upon AMF } \\
\text { species }\end{array}$ & (Huang et al., 2020) \\
\hline J. regia L. & & Rhizophagus irregularis & juglone transport $\uparrow$ & (Achatz et al., 2014a) \\
\hline $\begin{array}{l}\text { J. regia L. var. } \\
\text { 'Jizhuamian' }\end{array}$ & & Piriformospora indica & salt resistance $\uparrow$ & (Gao et al., 2019) \\
\hline $\begin{array}{l}\text { J. regia L. var. } \\
\text { 'Jizhuamian' }\end{array}$ & \multirow[b]{2}{*}{ Ectomycorrhiza } & Suillus tomentosus & resistance $\uparrow$ & (Gao et al., 2019) \\
\hline Carya illinoensis & & $\begin{array}{l}\text { Tuber melanosporum, } \\
\text { T. aestivum, } \\
\text { T. sinoaestivum, and } \\
\text { T. indicum }\end{array}$ & $\begin{array}{c}\text { growth } \uparrow ; \text { root vitality } \uparrow \\
\text { soil organic content } \uparrow\end{array}$ & (Zou et al., 2019) \\
\hline
\end{tabular}

$\uparrow$ and $\downarrow$ mean the significant $(P<0.05)$ increase and reduction of the paramater after inoculation with mycorrhizal fungi.

\section{Enhancement of drought tolerance}

The walnut tree has a high-water demand, so its production and tree growth can be influenced by soil drought stress (Vahdati et al., 2009). Behrooz et al. (2019) tried to use G. mosseae, G. etunicatum, and a mixture of both inoculated into one-year-old J. regia cv. 'Chandler' seedlings, and found that these AMF species significantly improved the contents of some metabolites under drought stress, such as total phenolic, proline, total soluble sugar, and starch, and also enhanced activities of peroxidase. In addition, among the AMF strains used by Behrooz et al. (2019), G. etunicatum was a more efficient mycorrhizal fungus for alleviating drought symptoms than either $G$. mosseae or the mix of both fungi. This positive role of AMF in walnut plants stimulates plant growth responses and nutrient acquisition, which would benefit drought adaption of walnut plants. The enhancement of drought tolerance in mycorrhizal walnut plants is dependent on AMF species.

\section{Delivery of juglone by mycorrhizal hyphae}

Walnut is a typical tree species with allelopathic effects, whilst juglone is a secondary metabolite of walnut in allelopathy (Ma et al., 2019). Juglone is found in leaves, roots, pericarp, exocarp, and bark of walnuts, and has been widely used for the treatment of cancer, stomach pain, cardiovascular diseases, and antitumor diseases (Binju et al., 2018; Ahmad et al., 2020). Achatz et al. (2014a) found that AMF (e.g. Rhizophagus irregularis) increased the soil-to-soil transfer of the allelochemical substance juglone, and mycorrhizal hyphae 
network could increase the juglone transfer between walnut plants. Juglone is slightly hydrophilic and thus occurs via water flowing along hyphae, as well as also dissolves in a liquid layer surrounding hypha in the soil matrix, which is absorbed and transported within the mycelium (Querejeta et al., 2003; Achatz et al., 2014b). However, whether this process is active or passive absorption by the hyphae is not yet clear.

\section{Physiological roles of an arbuscular mycorrhizal like fungus Piriformospora indica in walnut}

Some coastal saline areas have been planted with walnuts, and the soil salinity in these areas is high. Walnut is less salt tolerant and more sensitive to salinity (Zhang et al., 2002). P. indica, an arbuscular mycorrhizal like fungus, was discovered by Verma and other Indian scientists (1998) in the Thar Desert of northwestern India, and can colonize in the roots of many crops. The mycorrhizal like fungus has been documented the various role in plants, including enhancing plant growth, promoting the uptake of $\mathrm{N}, \mathrm{P}$, and other minerals, and enhancing crop tolerance to stresses (Zhang et al., 2002; Li et al., 2015; Wang et al., 2017; Yang et al., 2021). Gao et al. (2019) investigated the effects of $P$. indica on salt tolerance of walnuts. They found that the plant height, stem diameter, and leaf water content of $P$. indica-inoculated walnuts were higher than those of uninoculated treatments at high salt concentrations. Moreover, inoculation with $P$. indica also accelerated photosynthetic rate, chlorophyll content, and superoxidase activities, thereby, enhancing photosynthetic utilization efficiency of mycorrhizal walnuts and antioxidant defense systems, which in turn promoted the growth of the plants. The effect of $P$. indica in enhancing salt tolerance of walnuts would be better if combined with Suillus tomentosus (Gao et al., 2019). Future studies should further clarify the colonization characteristics of $P$. indica in walnut roots and the physiological benefits of mycorrhizas such as nutrient acquisition, water uptake and drought tolerance potential of walnut.

\section{Ectomycorrhizal fungi and walnut}

Diversity of ectomycorrhizal fungi in rhizosphere of walnut

Ectomycorrhizal (ECM) fungi form special structures with roots of most deciduous trees (e.g. oaks, beech trees, and conifers), including mycorrhizal snares, harting net, and extraradical mycelium (Smith and Read 2008; Ge et al., 2021). Ectomycorrhizae have been less studied in walnuts (Haug et al., 1991; Rivero et al., 2009). Tedersoo and Brundrett (2017) showed both ECM fungi and non-ECM fungi in the walut family. Ge et al. (2017) used the pyrosequencing technology and identified 96 ECM fungi species associated with walnut (Cary illinoinensis), belonging to 14 families. In these fungi, Scleroderma sp., Tomentella sp., Inocybe radiata, Russula pectinatoides, I. cf. calospora, and Tuber lyonii were the dominant species. Bonito et al. (2011) studied the ECM fungi diversity in C. illinoinensis in southern Georgia (USA) in terms of ITS and SSU rDNA sequence-based methods. They identified 44 ECM phylotypes, whilst Ascomycete genera included Cenococcum, Elaphomyces, Pachyphloeus, and Tuber and basidiomycete genera consisted of Hebeloma, Hymenogaster, Inocybe, Russula, Scleroderma, Sebacina Thelephora, and Xerocomus. Tuber and Scleroderma were abundant in these taxa, and T. lyonii and Tubersp. were the two most abundant species.

\section{Physiological roles of ectomycorrhizal fungi in walnut}

Ectomycorrhizae have characteristics such as mycorrhizal sheaths, mycorrhizal nets, and mycelium that do not enter the cells. Ectomycorrhizal fungi have the following effects on plants: a nutrient enrichment, stimulating nutrient (e.g. N, P, and K) and water absorption, improvement of soil structure, and enhancement of metabolisms and immunity of the host. He et al. (2013a) isolated Boletus edulis, Calvatia uiacina, and Cantharelles cibarius from walnut orchards. They further found that under the optimum combination (temperature of $20^{\circ} \mathrm{C}$, relative humidity of $70 \%$, and $\mathrm{pH} 6.0$ ), average mycelia biomass was up to $127.81 \mathrm{mg}$. In Carya illinoensis, inoculation with Tuber melanosporum, T. aestivum, T. sinoaestivum, and T. indicum showed root mycorrhiza after four months and the highest root mycorrhizal colonization was observed in six 
months by inoculation with $T$. indicum (Zou et al., 2019). The ectomycorrhizal fungi-inoculated $C$. illinoensis represented greater shoot $\mathrm{g}$ and root peroxidase activity than non-inoculated plants, suggesting that different Tuber strains especially $T$. indicum accelerated plant growth and stress tolerance of walnut trees. Further studies conducted by Yang et al. (2015) showed that $T$. indicum formed ectomycorrhiza after inoculated with T. indicum, along with light milky root tip, light yellow root base, yellowish brown root, and Harty's nets. Therefore, $C$. illinoensis is a very good host plant for $T$. indicum. Moreover, $C$. illinoensis is the only pecan species suitable for low altitude cultivation, and thus $C$. illinoensis becomes an important host used for commercial production of truffles, especially $T$. indicum.

\section{Conclusions}

Current information adequately displays the ability of walnut roots to establish symbiotic associations with both ectomycorrhizal fungi and AMF, and walnut roots can also be symbiotic with an arbuscular mycorrhizal like fungus $P$. indica. Since there are multiple mycorrhizal types in roots of walnut, it is not clear which mycorrhiza is dominant and how such mycorrhizal occurrence is associated with climate, soil conditions, and tree growth. The mycorrhizal symbiosis has been shown to promote nutrient uptake and plant growth, enhance drought resistance, and regulate nutrient transfer in walnut agroforestry systems (Figure 3). In particular, the symbiosis between walnut and truffle (an ECM fungus) produces more edible for truffle production, and such symbiosis not only increases economic benefits, but also has positive impacts on the growth of walnut. However, compared to mycorrhizae in other plants such as maize and citrus, the literature on walnut mycorrhizae is scarce. This provides the opportunity to understand walnut mycorrhizae. Future mycorrhizal research on walnut should focus on the following points:

(1) Mycorrhizal fungal diversity of walnuts must be identified, especially AMF communities, so as to provide a basis for walnut industry and healthy tree management along with few pesticides and other chemicals.

(2) How mycorrhizal fungi improve the uptake of $\mathrm{P}$ by walnuts, especially under soil $\mathrm{P}$ deficit conditions should be clarified.

(3) How mycorrhizal fungi enhance drought and salt tolerance of walnuts at the molecular level would be studied.

(4) Further studies need to increase the commercial production of truffles (e.g. T. indicum) using Carya illinoensi as a suitable host and also optimize the growth condition of the T. indicum- $C$. illinoensisystem.

(5) Many of walnut trees are planted in the mountainous areas where the soil is relatively poor, so the soil management of walnut is relatively important. In addition, AMF also release glomalin into the soil, contributing to soil nutrients such as soil organic carbon and nitrogen (He et al., 2020; Meng et al., 2020). The study of Cheng et al. (2020) showed the elevation of easily extractable glomalin-related soil protein in the soil after AMF inoculation in walnut. In the future, we also need to assess the benefits of glomalin in walnut orchard.

\section{Authors' Contributions}

Conceptualization: WYM and QSW; Data curation: WYM and QSW; Funding acquisition: YJX, KK and QSW; Project administration: YJX; Supervision: QSW; Writing - original draft: WYM and QSW; Writing -review and editing: QSW and KK. All authors read and approved the final manuscript. 


\section{Acknowledgements}

This work was supproted by the open fund of Hubei Key Laboratory of Economic Forest Germplasm Improvement and Resources Comprehensive Utilization (202019604), the Local Special Project for Science and Technology Development guided by the central government (2018ZYYD045), the National Innovation Alliance of Walnut Industry (NAWI), and the 2020 Joint Projects between Chinese and CEECs' Universities (202019).

\section{Conflict of Interests}

The authors declare that there are no conflicts of interest related to this article.

\section{References}

Achatz M, Morris EK, Müller F, Hilker M, Rillig MC (2014a). Soil hypha mediated movement of allelochemicals: arbuscular mycorrhizae extend the bioactive zone of juglone. Functional Ecology 28:1020-1029. https://doi.org/10.1111/1365-2435.12208

Achatz M, Michaela C, Rillig MC (2014b). Arbuscular mycorrhizal fungal hyphae enhance transport of the allelochemical juglone in the field. Soil Biology and Biochemistry 78:76-82. https://doi.org/10.1016/jsoilbio.2014.07.008

Ahmad T, Khan T, Alamgeer (2020). Juglone as antihypertensive agent acts through multiple vascular mechanisms. Clinical and Experimental Hypertension 42:335-344. https://doiorg/10.1080/10641963.2019.1665674

Alben AO, Boggs HM (1936). Zinc content of soils in relation to pecan rosette. Soil Science 41:329-332. https://doi.org/10.1097/00010694-193605000-00002

Behrooz A, Vahdati K, Rejali F, Lotfi M, Sarikhani S, Leslie C (2019). Arbuscular mycorrhiza and plant growthpromoting bacteria alleviate drought stress in walnut. HortScience 54:1087-1092. https://doi.org/10.21273/HORTSCI13961-19

Bender DA, Bender AE (2005). A dictionary of food and nutrition. Oxford University Press, Oxford. https://doi.org/10.1108/09504120510613328

Binju M, Padilla MA, Singomat T, Kaur P, Rahmanto YS, Cohen PA, Yu Y (2018). Mechanisms underlying acquired platinum resistance in high grade serous ovraian cancer-a mini review. Biochimica et Biophysica Acta 1863:371378. https://doi.org/10.1016/j.bbagen.2018.11.005

Bonito G, Brenneman T, Vilgalys R (2011). Ectomycorrhizal fungal diversity in orchards of cultivated pecan (Carya illinoinensis; Juglandaceae). Mycorrhiza 21:601-612. https://doi.org/10.1007/s00572-011-0368-0

Brundrett MC (2009). Mycorrhizal associations and other means of nutrition of vascular plants: Understanding the global diversity of host plants by resolving conflicting information and developing reliable means of diagnosis. Plant and Soil 320:37-77. http://doi.org/10.1007/s11104-008-9877-9

Chen Y (2018). Effects of arbuscular mycorrhizal fungi on the infection and growth of iris seedlings. The Thirteenth International Conference on China Urban Water Development and Expo of New Technologies and Facilities. Chongqing, China, pp 160-163.

Cheng WJ, Xu YJ, Huang GM, Rahman MM, Xiao ZY, Wu QS (2020). Effects of five mycorrhizal fungi on biomass and leaf physiological activities of walnut. Notulae Botanicae Horti Agrobotanici Cluj-Napoca 48:2021-2031. http://doi.org/10.15835/48412144

Dolcet-Sanjuan R, Claveria E, Camprubí A, Estaún V, Calvet C (1996). Micropropagation of walnut trees (Juglans regia L) and response to arbuscular mycorrhizal inoculation. Agronomie 16:639-645. http://doi.org/10.1051/agro:19961008

Durall DM, Gamiet S, Simard SW, Kudrna L, Sakakibara SM (2006). Effects of clearcut logging and tree species composition on the diversity and community composition of epigeous fruit bodies formed by ectomycorrhizal fungi. Canadian Journal of Botany 84:966-980. http://doi.org/10.1139/B06-045 
Gao Y, LiangY, Dong Z, Li HL, Liu BH, Fan XL, Zhou XY (2019). Effects of Piriformospora indica on the growth of walnut seedlings under salt stress. Journal of Arid Land Resources and Environment 33:194-198. http://dio.org/10.13448/j.cnki.jalre.2019.247

Ge W, Dong CB, Zhang ZY, Han,YF, Liang ZQ (2021). Symbiotic interaction between ectomycorrhizal fungi and endobacteria:a review. Microbiology China 1-15. http://doi.org/10.13344/j.microl.china.201155

Ge ZW, Brenneman T, Bonito G, Smith ME (2017). Soil pH and mineral nutrients strongly influence truffles and other ectomycorrhizal fungi associated with commercial pecans (Carya illinoinensis). Plant and Soil 418:493-505. http://doi.org/10.1007/s11104-017-3312-z

Haug I, Weber R, Oberwinkler F, Tschen J (1991). Tuberculate mycorrhizas of Castanopsis borneensis King and Engelhardtia roxburghiana Wall. New Phytologist 117:25-35. https://doi.org/10.1111/j.14698137.1991.tb00941.x

He HZ, Li Q, Liu YY, He YS, Zhang YW (2013a). Research on growth of ectomycorrhizal fungi from Juglans regia L. forest. Guangdong Agricultural Sciences 40:71-72. http://doi.org/10.16768/j.issn.1004-874x.2013.20.007

He HZ, Liu YY, Song JX, He YS, Tang J, Zhang YW (2013b). Research on disseminated technology of ectomycorrhizal fungi to Juglans regia L. Guizhou Science 31:72-74. http://doi.org/CNKI:SUN:GZKX.0.2013-02-016

He JD, Chi GG, Zou YN, Shu B, Wu QS, Srivastava AK, Kuča K (2020). Contribution of glomalin-related soil proteins to soil organic carbon in trifoliate orange. Applied Soil Ecology 154:103592. http://doi.org/10.1016/j.apsoil.2020.103592

Huang GM, Zou YN, Wu QS, Xu YJ, Kuča K (2020). Mycorrhizal roles in plant growth, gas exchange, root morphology, and nutrient uptake of walnuts. Plant, Soil and Environment 66:295-302. http://doi.org/10.17221/240/2020 PSE

Ishida TA, Nara K, Hogetsu T (2007). Host effects on ectomycorrhizal fungal communities: insight from eight host species in mixed conifer-broadleaf forests. New Phytologist 174:430-440. http://doi.org/10.1111/j.14698137.2007.02016.x

Jin L, Zhang H, Li B (2004). Mycorrhizal studies in China. Chinese Journal Applied and Environmental Biology 104:515520. http://doi.org/CNKI:SUN:YYHS.0.2004-04-026

Ju XH, Xu HY, Li Q, Chen S, Fang F (2020). Juglone inhibits epithelial mesenchymal transition of ovarian cancer cells by regulating NF- $\kappa \mathrm{B} /$ Snail pathway. Journal of Jilin Medical College 41:241-244. http://doi.org/10.13845/j.cnki.issn1673-2995.2020.04.001

Kao CC, Kung PH, Tai CJ, Tsai MC, Wu CC (2021). Juglone prevents human platelet aggregation through inhibiting akt and protein disulfide isomerase. Phytomedicine 82:153449. http://doi.org/10.1016/J.PHYMED.2020.153449

Li L, Wu HQ, Ma CY, Ren L, Wang LX, Qi ST (2015). Growth promotion and salt tolerance induction by Piriformospora indica colonization in Medicago truncatula. Microbiology China 42:1492-1500. http://doi.org/10.13344/j.microbiol.china.140749

Li RB, Jing YB, Mou JH, Ning DL, Li YP, Li SL, Li SH (2021). Correlation between arbuscular mycorrhizal in walnut orchards under different intercropping with soil factors. Journal of West China Forestry Science 50:71-78, 84. http://doi.org/10.16473/j.cnki.xblykx1972.2021.01.010

Lin SS, Sun XW, Wang XJ, Dou CY, Li YY, Luo QY, Sun L, Jin L (2013). Mycorrhizal studies and their application prospects in China. Acta Prataculturae Sinica 22:310-325. http://doi.org/CNKI:SUN:CYXB.0.2013-05-041

Liu HZ, Chi LH, Tu LKE, Li Y (2002). AM (arbuscular-mycorrhizas) fungi resources and their application in fruit trees. Journal of Jilin Agricultural University 24:50-55. http://doi.org/10.13327/j.jjlau.2002.02.015

Ma HY, Zhang WE, Pan XJ, Wei Q, Huang W (2019). Walnut allelopathy and its application prospects: a review. Jiangsu Agricultural Sciences 47:57-63. http://doi.org/10.15889/j.issn.1002-1302.2019.20.013

Ma SR, Shi MY, Li W, He Q, Cui HJ (2020). Research progress on ectomycorrhizal fungi of Salicaceae. Modern Agricultural Science and Technology 10:100-102. http://doi.org/CNKI:SUN:ANHE.0.2020-10-065

Melichar MW, Garrett HE, Cox GS (1986). Mycorrhizae benefit growth and development of Eastern black walnut seedlings. Northern Journal of Applied Forestry 3:151-153. http://doi.org/10.1093/njaf/3.4.151

Meng LL, He JD, Zou YN, Wu QS, Kuča K (2020). Mycorrhiza-released glomalin-related soil protein fractions contribute to soil total nitrogen in trifoliate orange. Plant, Soil and Environment 66:183-189. http://doi.org/10.17221/100/2020-PSE 
Mortier E, Lamotte O, Martin-Laurent F, Recorbet G (2020). Forty years of study on interactions between walnut tree and arbuscular mycorrhizal fungi. A review. Agronomy for Sustainable Development 40:43. http://doi.org/10.1007/s13593-020-00647-y

Pohjanen J, Koskimäki JJ, Sutela S, Ardanov P, Suorsa M, Niemi K, Sarjala T, Häggman H, Pirttilä AM (2014). Interaction with ectomycorrhizal fungi and endophytic Methylobacterium affects nutrient uptake and growth of pine seedlings in vitro. Tree Physiology 34:993-1005. http://doi.org/10.1093/treephys/tpu062

Ponder F (1984). Growth and mycorrhizal development of potted white ash and black walnut fertilized by two methods. Canadian Journal of Botany 62:509-512. http://doi.org/10.1139/b84-075

Querejeta JI, Egerton-Warburton LM, Allen MF (2003). Direct nocturnal water transfer from oaks to their mycorrhizal symbionts during severe soil drying. Oecologia 134: 55-64. http://doi.org/10.1007/s00442-002-1078-2

Rice EL (1984). Allelopathy. 2nd ed. Academic Press, New York, pp. 309-315.

Rivero SHT, Moorillon VGN, Borunda EO (2009). Growth, yield, and nutrient status of pecans fertilized with biosolids and inoculated with rizosphere fungi. Bioresource Technology 100:1992-1998. http://doi.org/10.1016/j.biortech.2007.12.078

Shi RH, Niu LJ (2018). Chinese Medicine Classic Diet. Shanghai Science Popularization Press, Shanghai, China.

Smith SE, Read FD (2008). Mycorrhizal Symbiosis. $3^{\text {rd }}$ edition. Academic Press, San Diego. http://doi.org/10.2136/sssaj2008.0015br

Song FQ, Yang GT, Meng FR, Tian XJ, Dong AR, Wu QY (2005). The effects of arbuscular mycorrhizal fungi on the radicular system of Populus ussuriensis seedlings. Journal of Nanjing Forestry University (Natural Sciences Edition) 29:35-39. http://doi.org/10.1360/biodiv.050121

Tedersoo L, Brundrett MC (2017). Evolution of ectomycorrhizal symbiosis in plants. In: Tedersoo L (eds) Biogeography of Mycorrhizal Symbiosis. Ecological Studies (Analysis and Synthesis), vol 230. Springer, Cham., pp 407-467. https://doi.org/10.1007/978-3-319-56363-3_19

Tuinen D, Tranchand E, Hirissou F, Wipf D, Courty PE (2020). Carbon partitioning in a walnut-maize agroforestry system through arbuscular mycorrhizal fungi. Rhizosphere 15:100230. http://doi.org/10.1016/j.rhisph.2020.100230

Twieg BD, Durall DM, Simard SW (2007). Ectomycorrhizal fungal succession in mixed temperate forests. New Phytologist 176:437-447. http://doi.org/10.1111/j.1469-8137.2007.02173.x

Vahdati K, Lotfi N, Kholdebarin B, Hassani D, Amiri R, Mozaffari MR, Leslie C (2009). Screening for drought-tolerant genotypes of Persian walnuts (Juglans regia L.) during seed. HortScience 44:1815-1819. http://doi.org/10.1007/s10658-009-9505-4

Verma S, Varma A, Rexer KH, Hassel A, Kost G, Sarbhoy A, Franken P (1998). Piriformospora indica, gen. et sp. nov., a new root-colonizing fungus. Mycologia 90:896-903. http://doi.org/10.2307/3761331

Wang HL, Zheng ZR, Zheng XD (2017). Effect of Piriformospora indica on the growth and nutritional quality of chinese celery (Apium graveolens L). Journal of Chinese Institute of Food Science and Technology 17:124-130. http://doi.org/10.16429/j.1009-7848.2017.06.017

Wang J (2015) Study on the efficienty of inoculation with arbuscular mycorrhizal fungi to walnut seeding. Master's thesis. Yangtze University, Jingzhou, China.

Wu QS, Srivastava AK, Zou YN (2013). AMF-induced tolerance to drought stress in citrus: A review. Scientia Horticulturae 164:77-87. http://doi.org/10.1016/j.scienta.2013.09.010

Wu QS, Srivastava AK, Zou YN, Malhotra SK (2017). Mycorrhizas in citrus: Beyond soil fertility and plant nutrition. Indian Journal of Agricultural Sciences 87:427-443.

Xie MM, Chen SM, Zou YN, Srivastava AK, Rahman MM, Wu QS, Kuča K (2021). Effects of Rhizophagus intraradices and Rhizobium trifolii on growth and N assimilation of white clover. Plant Growth Regulation 93:311-318. http://doi.org/10.1007/s10725-020-00689-y

Yang M, Liu CY, Tang P, Han D, Zheng LY, Chen B, Xiao YJ, Yang XF (2015). Synthetic mycorrhizal technique of tuber indicum inoculated with American hickory. Jiangsu Agricultural Sciences 43:267-269. http://doi.org/10.15889/j.issn.1002-1302.2015.09.089

Yang L, Zou YN, Tian ZH, Wu QS, Kuča K (2021). Effects of beneficial endophytic fungal inoculants on plant growth and nutrient absorption of trifoliate orange seedlings. Scientia Horticulturae 277:109815. http://doi.org/10.1016/J.SCIENTA.2020.109815

Zhang CH, Shen YB, Yin WL, Pan QH, Zhao SJ (2002). Effect of salt stress on photosynthesis and growth of four tree species seedings. Scientia Silvae Sinicae 38:27-31. http://doi.org/CNKI:SUN:LYKE.0.2002-02-005 
Zhang F, Wang P, Zou YN, Wu QS, Kuča K (2019). Effects of mycorrhizal fungi on root-hair growth and hormone levels of taproot and lateral roots in trifoliate orange under drought stress. Archives of Agronomy and Soil Science 65:1316-1330. http://doi.org/10.1080/03650340.2018.1563780

Zou J (2019). Effects of different Tuber infected Carya illinoensis on plant growth and root microecology. Master's thesis. Sichuan Agricultural University, Chengdu, China. http://doi.org/10.27345/d.cnki.gsnyu.2019.000206

Zou YN, Wu QS, Kuča K (2021a). Unravelling the role of arbuscular mycorrhizal fungi in mitigating the oxidative burst of plants under drought stress. Plant Biology 23(S1):50-57. https://doi.org/10.1111/PLB.13161

Zou YN, Zhang F, Srivastava AK, Wu QS, Kuča K (2021b). Arbuscular mycorrhizal fungi regulate polyamine homeostasis in roots of trifoliate orange for improved adaptation to soil moisture deficit stress. Frontiers in Plant Science 11:600792. https://doi.org/10.3389/FPLS.2020.600792
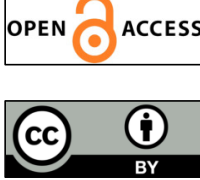

The journal offers free, immediate, and unrestricted access to peer-reviewed research and scholarly work. Users are allowed to read, download, copy, distribute, print, search, or link to the full texts of the articles, or use them for any other lawful purpose, without asking prior permission from the publisher or the author.

License - Articles published in Notulae Botanicae Horti Agrobotanici Cluj-Napoca are Open-Access, distributed under the terms and conditions of the Creative Commons Attribution (CC BY 4.0) License. (c) Articles by the authors; UASVM, Cluj-Napoca, Romania. The journal allows the author(s) to hold the copyright/to retain publishing rights without restriction. 